Букуру, Ф.К. Алимова, З.А. Канарская /Вестник Казанского технологического университета. - 2014. - Т. 17, №13. - С.288-291

3. Хамагаева, И. С. Исследование пробиотических свойств комбинированной закваски / И. С. Хамагаева, И. В. Бояринева, Н. Ю. Потапчук // Техника и технология пищевых производств. - 2013. - №1 - - С. 54-58.

4. Горальчук, А.Б. Реологічні методи дослідження сировини і харчових продуктів та автоматизація розрахунків реологічних характеристик: навчальний посібник / А.Б. Горальчук, П.П. Пивоваров, М.І. Погожих, В.В. Полевич, П.В. Гурський / Харк. держ. ун-т харч. та торгівлі. - Харків, 2006. - 63 с.

\title{
ЦИТ: иа117-064
}

DOI: $10.21893 / 2415-7538.2016-05-1-064$

\section{ДИНАМІЧНА МОДЕЛЬ ЕКОНОМІЧНОГО ПОТЕНЦАЛУ СИСТЕМИ ПОРТІВ}

Одеський Наџіональний морський університет, Мечникова 34, 65029

Girina O.B. \author{
PORTABLE SYSTEM \\ Odessa National Maritime University, \\ Odessa, Mechnikova 34, 65029
}

DYNAMIC MODEL OF THE ECONOMIC POTENTIAL OF THE

Анотація: Розглядається динамічна економіко-математична модель транспортної системи доставки вантажів через морські порти для оиінки економічного потенціалу портів в нинішньому та перспективному стані в умовах їх розвитку з вибором структури інвестиційних витрат на втілення варіантів їх розвитку. В якості критерію задачі верхнього рівня розглядається максимум чистого приведеного грошового потоку від перевезення $і$ перевалки вантажів. Пропонується узгодження рішення задачі верхнього рівня 3 задачами другого рівня для деталізащії ресурсів $i$ варіантів розвитку стивідорних компаній портів. Цей підхід дає можливість оцінити ринкову вартість компаній як узагальнюючий показник їх економічного потенціалу та ризики зменшення корисності активів.

Ключові слова: економічний потенщіал, морські порти, виробничі, фінансові ресурси, варіанти розвитку, структура капіталу, стивідорні компанії, ринкова вартість,корисність активів, фінансові ризики.

Abstract: We consider a dynamic economic and mathematical model of transport system of cargos delivery through ports to assess the economic potential of the ports in the current and prospective state of development in terms of the choice of the structure of investment costs to implement options for their development.. For the top level model it was being considered the criterion maximum net present cash flow from the carriage and handling of cargo. It is proposed harmonization solution toplevel objectives for the second level of detail resources and development options stevedoring companies. This approach makes it possible to estimate the market value 
of companies as general indicators of their economic potential and risks of impairment.

Keywords: economic potential, seaports, industrial, financial resources, development option, capital structure, stevedoring companies, market value, impairment., financial risks.

Постановка проблеми. В умовах ринку, що характеризується нестабільністю попиту та пропозиції, мінливістю цін на товари та послуги, змінами в конкурентному середовищі, значення можливостей підприємства, особливо на тривалу перспективу, потребує оцінки його потенціалу. Оцінка економічного потенціалу підприємства належить до пріоритетних напрямків прийняття управлінських рішень.

Обзор літератури. Потенціал підприємства - це складна поліструктурна система, причому основною його ознакою $є$ динамічність, тобто він змінюється кількісно та якісно високими темпами. Головною проблемою при дослідженні потенціалу підприємства $\epsilon$ те, що його елементи взаємозв'язані та діють одночасно.[2,3] Ця задача повинна вирішуватися на базі системного підходу, в рамках якого будь-який об'єкт повинен описуватися, по-перше, як елемент вищого рівня, по-друге, як цілісне явище, по-третє, з точки зору його структури [2]. Це означає, що опис зачіпає надсистему, систему і підсистему (елемент) i повинен бути багаторівневим. Для системи портів надсистемою вищого рівня $\epsilon$ вся транспортна система доставки вантажів, а підсистемами є окремі порти зі своєю структурою ресурсів.

Сама категорія економічного потенціалу підприємства потребує оцінки на базі показника, який може висвітити усі види його діяльності. Багато дослідників пропонують для цієї цілі показник ринкової вартості об'єкту [3]. Ринкова вартість активів компанії може бути ознакою зниження її корисності, якщо протягом деякого часу вона буде менше їх балансової вартості $[4,5]$. Для визначення економічного потенціалу системи підприємств, який базується на обліку економічних результатів поточної та майбутньої господарської діяльності, може використовуватись результатна концепція. Характерною особливістю результатної концепції $є$ те, що капіталізована вартість формується за рахунок показників прибутковості всього майнового комплексу, а в ряді випадків і за рахунок нематеріальних активів. Це означає, що у вартість входять всі виробничі фактори, які спричиняють прибутковість об'єкта та системи об'єктів. У практиці оцінки найбільш поширене застосування показника чистого грошового потоку - він краще корелює з ринковою вартістю майна.

Завдання дослідження: вирішити проблему оцінки економічного потенціалу системи портів на базі системного підходу у рамках транспортної системи доставки вантажів, розглядаючи у задачі усі головні ресурси портів.

Основний матеріал досліджень. Під оцінкою економічного потенціалу нами розуміється визначення його величини у вартісному вираженні.

Економічний потенціал системи портів - інтегральний показник, який відображає сукупні можливості їх ресурсів, породжувані організацією використання цих ресурсів, потенціалом управління, який реалізується взаємодією усіх учасників транспортного процесу та усіх ресурсів. 
Для оцінки економічного потенціалу системи портів нами пропонується дворівнева система економіко-математичних моделей: на першому рівні модель доставки вантажів від відправників до одержувачів при розподілі вантажів між портами і видами транспорту з урахуваннням варіантів розвитку портів; на другому рівні - моделі визначення економічного потенціалу розвитку кожного окремого порту (стивідорних компаній) [7].

В якості критерію задачі верхнього рівня розглядається максимум чистого дисконтованого грошового потоку від доставки вантажів в системі портів i видів транспорту за плановий період; на нижньому рівні економічний потенціал розвитку окремого порту (сукупності стивідорних компаній) визначається за критерієм максимум чистого дисконтованого грошового потоку компанії від виробничої діяльності. Аналіз цієї задачі виконаний в роботі [7].

Для цілей аналізу економічного потенціалу у звітньому періоді згідно 3 бухгалтерським стандартом 28 необхідно майбутні грошові потоки попередньо оцінювати для активу в його нинішньому стані. При визначенні майбутніх грошових потоків від активу не враховують очікувані надходження або вибуття грошових коштів в результаті майбутній реструктуризації, по якій підприємством не визнано зобов'язання; майбутніх капітальних інвестицій для збільшення первісного рівня корисності активу; майбутніх грошових потоків від фінансової діяльності; сплати (відшкодування) податку на прибуток. [5]

Далі розглядається модель верхнього рівня для оцінки економічного потенціалу системи портів спочатку у стані активів без урахування їх можливого розвитку. У цій моделі використовуються наступні позначення:

$x_{i k t}^{p H}$ - обсяг перевезень вантажу найменування $p$ між регіоном $i$ та портом $k$, який перевантажується на перевантажувальному комплексі $H$ в році $t x_{k j t}^{p s}$ обсяг перевезень вантажу найменування $p$ між портом $k$ i районом $j$ видом транспорту $s$ в році $t{ }^{x_{k(t-1)}^{p}}, x_{k t}^{p}$ - залишок вантажу р в порту $\mathrm{k}$ на початок $\mathrm{i}$ кінець року $\mathrm{t}$; $f_{i k t}^{p H}$, - чистий прибуток флоту на одну тонну вантажу при перевезенні вантажу $p$, відповідно, на ділянці $(i k)$ у році $t$; перевалці в порту $k$ на перевантажувальному комплексі $H$ в році $t$;

$f_{k t}^{p H t}$ - чистий прибуток при перевалці однієї тонни вантажу $p$ на перевантажувальному комплексі $H$ порту $k$ в році $t$; $f_{k j t}^{p s}$ - чистий прибуток на одну тонну вантажу $p$ при перевезенні на ділянці $(\mathrm{kj})$ транспортом $s$ у році $\mathrm{t}$;

$Q_{i t}^{p}$ - обсяги ввезення (вивезення) за родами вантажів $p$ та регіонам світу $i$ в році $t ; G_{j t}^{p}$ - обсяги вивезення (ввезення) за родами вантажів $p$ і районам виробництва (споживання) $j$ в році $t ; B_{k t}^{H}$ бюджет часу перевантажувального комплексу $H$ порту $k$ в році $t$; $b_{k t}^{p H}$ - трудомісткість перевалки вантажу $p$ на причалах $H$ порту $k$ в році $t$ (чол-год./т); $\Pi_{k t}^{p H}-$ пропускна спроможність 
перевантажувального комплексу $H$ порту $k$ по вантажу $p$ в році $t$ (т.т.); $d_{k j}^{s t}$ провізна спроможність транспорту $s$ на напрямку $k j$ в році $t$ (тонно-милі); $L_{k j}$ відстань перевезення на ділянці $k j$; $\omega_{p s}$ - характеристика вантажопідйомності транспорту $s$ п перевезення вантажу $p$; $r$ - норма прибутковості;

$$
\begin{aligned}
& Z_{\max }=\left[\sum_{t} \sum_{k} \sum_{H} \sum_{p} f_{k t}^{p H} \cdot \sum_{i} x_{i k t}^{p H}+\sum \sum \sum \sum \sum f_{i k t}^{p H} \cdot x_{i k t}^{p H}+\right. \\
& \left.+\sum_{t} \sum_{k} \sum_{j} \sum_{p} \sum_{s} f_{k j t}^{p s} \cdot x_{k j t}^{p s}\right] \cdot(1+r)^{-t} \\
& \sum_{k} \sum_{H} x_{i k t}^{p H} \leq Q_{i t}^{p}, \forall i, p, t \\
& \sum_{k} \sum_{s} x_{k j t}^{p s} \leq G_{j t}^{p}, \forall j, p, t \\
& \sum_{p} \sum_{i} b_{k t}^{p H} \cdot x_{i k t}^{p H} \leq B^{H}, \forall k, H, t \\
& \sum_{p} \sum_{i} x_{i k t}^{p H} / \Pi_{k t}^{p H} \leq 1, \forall k, H, t \\
& \sum_{p} L_{k j} / \omega_{p s} \cdot x_{k j t}^{p s}, \forall k, j, s, t \\
& \sum_{i} \sum_{H} x_{i k t}^{p H}+x_{k(t-1)}^{p}=\sum_{j} \sum_{s} x_{k j t}^{p s}+x_{k t}^{p}, \forall k, p \in P^{+}, t \\
& \sum_{i} \sum_{H} x_{i k t}^{p H}+x_{k(t)}^{p}=\sum_{j} \sum_{s} x_{k j t}^{p s}+x_{k(t-1)}^{p}, \forall k, p \in P^{-}, t \\
& F_{k t}^{H}=\sum_{i} \sum_{p} f_{k t}^{p H} \cdot x_{i k t}^{p H}, \forall H, k, t \\
& x_{i k t}^{p H} \geq 0, \quad x_{k j t}^{p s} \geq 0
\end{aligned}
$$

(1)- цільова функція на максимум чистого дисконтованого грошового потоку транспортної системи доставки вантажів від реалізації перевезення та перевантаження вантажів через перевантажувальні комплекси системи портів;(2) - обмеження на обсяг ввезення (вивезення) вантажу найменування $p$ в (з) регіону $i$ в році $t$; (3) - обмеження на обсяги вивезення (ввезення) вантажів найменування $p$ з (в) районів $j$ на території України; (4) - обмеження щодо неперевищення бюджету часу в нормо-годинах перевантажувального комплексу $H$ порту $k$ в році $t ;(5)$ - обмеження щодо неперевищення пропускної спроможності перевантажувального комплексу $H$ порту $k$ в році $t$;

(6) - обмеження на провізну спроможність транспорту $s$ на напрямках $k j$ в році $t$; (7), (8) - балансові співвідношення для кожного роду вантажу $p$ за видами плавання (ввіз і вивіз відповідно) і портам перевалки $k$ про те, що кількість прибулого в порт вантажу в період $t$ дорівнює кількості 
відправленого вантажу з урахуванням початкової та кінцевої кількості вантажу даного найменування ;

(9)- розрахунок чистого прибутку порту $k$ в році $t ;(10)$ - умова невід'ємності змінних.

Нормативи чистого прибутку перевізників та стивідорних компаній порту розраховані по звітним даним минулого періоду i відображують фактичну організацію роботи транспорту і внутрішньопортову спеціалізацію. У такому стані економічний потенціал характеризує рівень теперішнього використання наявних можливостей і резервів.

Категорія економічного потенціалу містить елементи майбутнього розвитку.

Однією 3 цілей оцінювання економічного потенціалу $\epsilon$ визначення напрямів розвитку та можливостей підприємства щодо як отримання збільшення, так і зменшення чи навіть втрати вигод.

Щоб врахувати можливі істотні позитивні зміни активу або способу його використання, які можуть вплинути на діяльність транспортних підприємств та відновлення корисності активів портів, пропонується поширити модель (1)-(10) умовами (11)-(22), які враховують варіанти розвитку портів у межах всієї транспортної системи. В цих умовах прийняті позначення:

$y_{k t}^{\alpha H}$ - булева змінна про прийняття варіантів розвитку $\alpha$ на перевантажувальному комплексі $H$ порту $k$ в році $t$;

$0 \leq n_{k}^{t} \leq 1$ - норма нагромадження в порту $k$ в році $t$;

$S_{k t}^{\alpha H}$ - обсяг інвестиційних витрат за варіантом розвитку $\alpha_{\text {на }}$ перевантажувальному комплексі $H$ порту $k$ в році $t ; I_{t}$ - загальний обсяг капітальних вкладень у році $t ; R_{t}$ - загальний обсяг позикових коштів у році $t$; $C r_{k t}^{\alpha H}$ - обсяг позикових коштів, необхідних по варіанту розвитку $\alpha$ комплексу $H$ в порту $k$ у році $t$.

$$
\begin{gathered}
\sum_{\alpha} y_{k t}^{\alpha H} \leq 1, \forall k, H, t \\
\sum_{H} \sum_{k} \sum_{\alpha} S_{k t}^{\alpha H} \cdot y_{k t}^{\alpha H} \leq I^{t}, \forall t \\
\sum_{H} \sum_{k} \sum_{\alpha} C r_{k t}^{\alpha H} \cdot y_{k t}^{\alpha H} \leq R^{t}, \forall t \\
R^{t}=I^{t}-\sum_{k} n_{k}^{t} \cdot \sum_{H} F_{k t}^{H}, \forall t \\
A_{k t}^{\alpha H}=\sum_{t=\pi}^{T} n_{k t}^{\alpha H} \cdot S_{k t}^{\alpha H}, \forall \alpha, k, H, t \\
b_{k(t+1)}^{p H} b_{k t}^{p H}-\sum_{\alpha} y_{k t}^{\alpha H} \cdot \Delta b_{k t}^{\alpha p H}, \forall k, H, p, t
\end{gathered}
$$




$$
\begin{gathered}
f_{k(t+1)}^{p H}=f_{k t}^{p H}+\sum_{\alpha} y_{k t}^{\alpha H} \cdot \Delta f_{k t}^{\alpha p H}, \forall k, H, p, t \\
f_{i k(t+1)}^{p H}=f_{i k t}^{p H}+\sum_{\alpha} y_{k t}^{\alpha H} \cdot \Delta f_{i k t}^{\alpha p H}, \forall i, k, H, p, t \\
B_{k(t+1)}^{H}=B_{k t}^{H}+\sum_{\alpha} y_{k t}^{\alpha H} \cdot \Delta B_{k t}^{\alpha H}, \forall k, H, t \\
\Pi_{k(t+1)}^{p H}=\Pi_{k t}^{p H}+\sum_{\alpha} y_{k t}^{\alpha H} \cdot \Delta \Pi_{k t}^{\alpha p H}, \forall k, H, p, t \\
N P V_{k}^{H}=\left[\sum_{t} F_{k t}^{H}+\sum_{t} \sum_{\alpha}\left(C r_{k t}^{\alpha H}+A_{k t}^{\alpha H}-S_{k t}^{\alpha H}\right) \cdot y_{k t}^{\alpha H}\right] \cdot(1+r)^{-t} \geq 0, \forall H, k \\
x_{i k t}^{p H} \geq 0, x_{k j t}^{p s} \geq 0, y_{k t}^{\alpha H} \in\{0,1\}, 0 \leq n_{k}^{t} \leq 1
\end{gathered}
$$

(11)- обмеження про те, що для кожного перевалочного комплексу $H$ порту $k$ в році $t$ може бути обрано не більше одного варіанту розвитку;(12) обмеження на обсяг капітальних вкладень у році $t$; $(13)$ - обмеження на величину позикових коштів в році $t$; (14) - умова формування обсягу позикових коштів в році $t$;

(15)- розрахунок амортизаційних відрахувань по уведеним в дію основним фондам, де $S_{k t}^{\alpha H}, n_{k t}^{\alpha H}$,відповідно, вартість основних фондів і норма амортизації за варіантом розвитку $\alpha$ на перевантажувальному комплексі $H$ порту $k$ в році $t$;

(16)-(20) - обмеження про зміну, відповідно, трудомісткості перевантаження вантажів у портах, чистого прибутку порту на одну тонну вантажу, чистого прибутку флоту на одну тонну вантажу, бюджету часу в нормо-годинах i пропускної здатності за родами вантажів в тис. тонн перевантажувальних комплексів $H$ в результаті прийняття варіанту розвитку $\alpha$ на перевантажувальному комплексі $H$ порту $k$ в році $t$;

(21) - умови ефективності обраного варіанту розвитку ${ }^{\alpha}$ комплексу $H$ порту $k$, в яких $F_{k t}^{H}$ - чистий прибуток від виробничої діяльності комплексу $H$ порту $k$ в році $t$, розрахований по формулі (9); (22) - умова невід'ємності змінних.

Розрахунки на основі моделі (1)-(22) розподілення вантажів між портами та видами транспорту 3 вибором варіантів розвитку портів дозволяють перераховувати технологічні та фінансові нормативи експлуатації портів, що може привести до відновлення корисності їх активів.

Результати. Стратегія поточного і довгострокового планування роботи портів залежить від отриманого співвідношення між пропускною спроможністю системи портів $\sum_{k} \Pi_{k t} \sum_{i} \sum_{p} Q_{i t}^{p}$ сумою вантажів, які пред'являються до перевезення і перевантаження на рік $t$ :

$$
\sum_{i} \sum_{p} Q_{i t}^{p} \geq \text { або } \leq \Pi_{k t}
$$


Це співвідношення впливає на обсяги роботи портів, тобто пов'язане з їх виробничими ризиками, що проаналізовано у статті [6]. Грошові надходження портів залежать від обсягів перевантаження i пов'язані 3 розміром їх виробничого потенціалу(пропускною спроможністю). Фінансові ризики обумовлені структурою капіталу портів, яка залежить від обраною в моделі оптимальної норми нагромадження $n_{k}^{t^{*}}$ порту і залежних від неї обсягів кредитного фінансування. Оптимальна структура капіталу впливає на середню зважену вартість капіталу за умов змішаного фінансування розвитку компаній порту i використовується як норма капіталізації $H_{k}^{t}$ прибутку портів в розрахунках їх ринкової вартості (26).

Модель (1)-(22) дозволяє розрахувати економічний потенціал портів як поєднання виробничого і фінансового потенціалів портів завдяки потенціалу управління транспортною системою. Таким чином, економічний потенціал системи портів пропонується розрахувати як теперішню вартість майбутніх чистих грошових надходжень від реалізації послуг перевантаження в системі портів:

$$
E \prod_{\text {nopmis }}^{\text {cucmen }}=\sum_{k} \sum_{t} C F_{k t}=\sum_{t} \sum_{k} \sum_{H} \sum_{p} f_{k t}^{p H} \cdot \sum_{i} x_{i k t}^{p H} \cdot(1+r)^{-t}
$$

Розрахунки по формулі (24) повинні узгоджуватися 3 теперішньою вартістю грошових надходжень компаній порту (25) у моделях їх розвитку [7] і використовуються для оцінки їх ринкової вартості (26)

$$
\begin{gathered}
C F_{k t}=\sum_{t=1}^{N} \sum_{H} \sum_{p} f_{k t}^{p H} \cdot \sum_{i} x_{i k t}^{p H} \cdot(1+r)^{-t} \\
E \Pi_{\text {nорта }}=L_{\text {nopma }}=\frac{\sum_{t=1}^{N} C F_{k t}}{H_{t}^{k}}
\end{gathered}
$$

Ринкова вартість активів порту вимірює економічний потенціал окремої компанії або порту. Бухгалтерським стандартом №28 передбачено розрахунок втрати від зменшення корисності активів - суми, на яку балансова (залишкова) вартість активу перевищує суму його очікуваного відшкодування. Сума очікуваного відшкодування активу - найбільша 3 двох оцінок: чиста вартість реалізації активу (26) або теперішня вартість майбутніх чистих грошових надходжень від активу (25). Зменшення корисності активів можна розглядати як показник ризиковості розвитку портів.

Висновки. Пропонується оцінка економічного потенціалу портів за моделлю (1)-(10) у нинішньому стані і розрахунки корисності їх активів. Для оцінки економічного потенціалу у перспективному періоді в статті використовується розширена модель (1)-(22) з урахуванням варіантів розвитку портів для оцінки відновлення їх корисності. Системний підхід до визначення економічного потенціалу дозволяє використовувати економічний потенціал як критерій прийняття різних управлінських рішень, наприклад, взяття портів в оренду або концесію. 


\section{Література}

1.И.В.Морозова, Н.И.Ляшенко, Л.П.Суворова. Оптимизация функционирования составных частей взаимосвязанных транспортной и логистической систем.//Методи та засоби управління розвитком транспортних систем:Зб.наук.праць.-Одеса:ОНМУ,2005- Вип.10.- С.6-23

2.Социально-экономический потенциал региона: монография/под общ. ред. проф. О.Ф. Балацкого - Сумы: Университетская книга,2010.-364c.

3.Костирко Р.О. Контроль і аналіз в системі управління економічним потенціалом господарюючого суб'єкта. Методологія i організація:Монографія/Р.О.Костирко.- Луганск:СНУ ім..Даля,2010.-728 с.

4. Економічний потенціал підприємства:обліково-статистичний та інформаційно-технологічний контекст.[моногр.]/[Войнаренко М.П.,Осауленко О.Г., Скоробогата Л.В., Шевчук В.О.];за ред.О.Г.Осауленка.-К.:ДП «Інформ.аналіт.агенство»,2010.-223c.

5.Положення(стандарти)бухгалтерського обліку28 «Зменшення корисності активів», затверджено Наказом Міністерства фінансів України від 24.12.2004 p.№ 817/Бухгалтерія.-2005.-№5.-С.11-16.

6.Гирина О.Б. Экономико-математическое моделирование производственного потенциала системы портов. Научн.тр. Sworld :вып.№3(44)том 1,2016.-С.1-4

7.Гирина О.Б. Динамічна модель оцінки економічного потенціалу розвитку стивідорної компанії. // Розвиток методів управління та господарювання на транспорті: Зб. наук. праць.- Одеса:ОНМУ,2015.-Вип.2(51).-С.38-54.

Стаття відправлена: 02.04.2017 p.

(C) Гіріна О.Б.

\section{ЦИТ: иа117-081}

DOI: 10.21893/2415-7538.2016-05-1-081

УДК 656.1:658.5

ИССЛЕДОВАНИЕ ВОЗМОЖНОСТИ ПРИМЕНЕНИЯ КОНЦЕПЦИИ «БЕРЕЖЛИВОЕ ПРОИЗВОДСТВО» ДЛЯ РЕШЕНИЯ ПРОБЛЕМЫ УБЫТОЧНОСТИ ГОРОДСКОГО ПАССАЖИРСКОГО ТРАНСПОРТА RESEARCH ON "LEAN PRODUCTION" APPLICATION FOR LOSSES OF CITY TRANSPORT PROBLEM SOLUTION

к.т.н., доц. Пыталева О.А. / c.t.s., as.prof. Pytaleva O.A. студент магистр, Казармщикова А.B. / Undergraduate Student Kazarmschikova A.V. Магнитогорский государственный технический университет им. Г.И. Носова Магнитогорск, пр. Ленина, 38, 455000

Nosov Magnitogorsk State Technical University Magnitogorsk, Prospect Lenina, 38, 455000

Аннотачия. Статья посвящена проблеме убыточности городского пассажирского транспорта. Приведен анализ состояния крупных и средних организаций транспорта по видам экономической деятельности. Основной причиной убыточности общественного транспорта является рост количества личных автомобилей. Чтобы коренным образом улучшить ситуачию, необходимо обеспечить качественный прорыв в системе городского 